Al-Azhar Bull. Sci. Vol. 24, No. 2 (Dec.): pp. 9-19, 2013.

DETERMINATION OF HEAVY ELEMENTS CONCENTRATIONS IN COSMETICS COMMONLY USED IN ARABIC REGIONS

M.M. SHERIF and O.R. ABDURAHEM*

Department of Physics, Faculty of science, Cairo University, Giza 12613, Egypt

*E-mail: asiza14@yahoo.com

\begin{abstract}
Forty two samples of cosmetics including twenty one artificial cosmetics (makeup and skin care items) and twenty-one traditional cosmetics used particularly in Arabic regions were analyzed to determine theconcentrations of $\mathrm{Pb}, \mathrm{Cd}, \mathrm{As}, \mathrm{Hg}, \mathrm{Ni}, \mathrm{Co}, \mathrm{Cr}, \mathrm{Mo}, \mathrm{Si}, \mathrm{Sr}$ and $\mathrm{V}$. Inductively Coupled Plasma-Optical Emission (ICP- OES)spectrometer were applied for elemental analysis. The outcome of this paper shows that lead and cadmium concentrations are so high in all kohl samples. The higher concentrations of arsenic were in hand cream samples imported from Israel (43.37 and $52.71 \mathrm{ppm}$ ), while the higher concentration of mercury is $585.16 \mathrm{ppm}$. The amounts of heavy elements that may be absorbed into the body from daily usage of lipsticks and kohl have been calculated.
\end{abstract}

Keywords: Heavy elements, Cosmetics, ICP-OES, Traditional cosmetics in Arabic regions.

\title{
Introduction
}

Cosmetics are widely used throughout the world including makeup and skin care items. In addition,some traditional materials particularly in Arabic regions and some countries of south EastAsia. For example, kohl (traditional powder eyeliner, it's usage in the Arabic region originated to the Arabic and Islamic heritage because of the Arabs thoughts of kohl's benefits: wide eye, pure it from dust, impurities and protects it from hot sunshine), henna (henna is a plant used to dye and beautify the skin and also used to dye hair), clay, talc stone and alum stone. These traditional materials are taken directly as raw materials from nature and used to beautify and take care ofthe skin. This research is a part of our work which aimingto study natural radioactivity concentrations in cosmetics, as well as the concentrations of some other heavy elementsand explaininghow serious they are.Besides, this research questions whether those cosmetics are safe to use or not and we will recommend some advice to minimize the hazard of using these materials. In this paper, we will shed light only on the elemental analysis using (ICP-OES) technique.

Based on many interesting other studies of the concentrations of the four most toxic elements (lead, mercury, arsenic and cadmium) in cosmetics, we are interested 
to study the heavy elements concentrations in cosmetics in order to contribute the development of standards and specific levels of these elements allowed in the Arabic nations. We depend on the daily use and prices of these products.It is worth mentioning that most of the States did not establish allowable levels of heavy metals in cosmetics except some developed countries such as America, Canada and some European Union countries. Table (1) shows the allowable levels of heavy metals in cosmetics set by these states: Canada [1], Germany [1] and the U.S.A [3]. It can be noticed that American levels are ranging between Canadian and German limits.

Heavy metals may harm human health. After having exposure to those metals, they accumulate in the internal organs of the human body causing damage over time. For example, lead is accumulated in various tissues, especially bone, but also in the liver, kidneys, pancreas and lungs. Furthermore, it causes several health effects: disruption the biosynthesis of hemoglobin and anemia, a rise in blood pressure, kidney damage, miscarriages, disruption of nervous systems, declined fertility of men through sperm damage and diminished learning abilities of children. If $\mathrm{Pb}$ is ingested, adults will absorb about $10 \%$ into blood while children will absorb about 40 to $50 \%$ [3]. After immediate exposure, humans are able to get rid $50 \%$ of lead within two or six weeks [3], but it takes 25 to 30 years to overcome $50 \%$ of lead that has accumulated in the body over time [3]. Moreover, lead absorption through the skin is very little and can be eliminated through perspiration and organic fluids,so it doesn't represent a health hazard as ingestion pathway. Further report [4] releases lead absorption rate in skin unguents which is higher than powders products.Also,there is no evidence of intoxication risks when unguents containing $\mathrm{Pb}$ in the concentration of $0.4 \%$ (4000 ppm) are applied on the human skin.

Table (1) Allowable levels of some heavy elements in cosmetics

\begin{tabular}{|c|c|c|c|}
\hline \multirow{2}{*}{ Element } & \multicolumn{3}{|c|}{ Allowable level in ppm } \\
\cline { 2 - 3 } & $\begin{array}{r}\text { In } \\
\text { Canada } \\
{[1]}\end{array}$ & $\begin{array}{r}\text { In Germany } \\
{[1]}\end{array}$ & $\begin{array}{r}\text { In USA } \\
{[2]}\end{array}$ \\
\cline { 1 - 1 } & 3 & 5 & 3 to 5 \\
Arsenic & 3 & 1 & 1 to 3 \\
Mercury & 3 & 5 & 5 to 15 \\
\cline { 1 - 1 } Cadmium & 10 & 20 & 10 to 20 \\
\cline { 1 - 1 } Lead & 5 & 10 & - \\
\cline { 1 - 1 } Antimony & 5 & - & 20000 \\
\cline { 1 - 1 } Titanium & - & & \\
as(Tio2) & & &
\end{tabular}


Arsenic is one of the most toxic elements that can be found. It can cause irritation of the stomach and intestines, decreased production of red and white blood cells, skin changes and intensify the chances of cancer development. A lethal dose of As oxide is generally regarded as $100 \mathrm{mg}$. It is suggested that humans getrid50\% of As from the body between two and 40 days later, although it will tend to accumulate in skin and hair over time [5].

Absorption of lower concentrations of cadmium over time may cause kidney damage, bone deformity and Osteoporosis [6]. Humans overcome $50 \%$ of cadmium from the body 10-12 years after absorbing those concentrations[7]. Mercury has a number of health effects: disruption of the nervous system, damage to brain functions, DNA damage and chromosomal damage, allergic reactions, resulting in skin rashes, tiredness ,headachesand miscarriages.

The effects of stable $\mathrm{Sr}$ compounds are based on its homology to calcium: strontium can replace calcium in most biological processes, so that it could be absorbed into the blood first, but most of it ends up in bones. The absorption of $\mathrm{Sr}$ from the skin is slow and unimportant. Other heavy elements can also cause several health influences when up taking in certain levels.Ni is actually the leading reason for dermatitis contact. However, small amounts of other toxic elements may sensitize the immune system and trigger an allergic reaction due to the cumulative effects of different metals to which the organism is exposed [8]. In fact, in some cases, allergic reactions associated to nickel are also connected with higher levels of sensitivity to $\mathrm{Cr}$, Co and $\mathrm{Cd}$ (It was proposed that cosmetic products must contain less than 5 ppm[8]).

Most cosmetics are applied to the skin. Thus, the heavy elements are absorbed through the skin and oral exposure can occur for cosmetics used in and around the mouth. Besides, from hand-to-mouth contact after exposure to cosmetics containing heavy metal impurities. Inhalation exposure is expected to be negligible [1]. The objective of the present workis to determine the concentrations of $\mathrm{As}, \mathrm{Cd}, \mathrm{Co}, \mathrm{Cr}, \mathrm{Mo}, \mathrm{Ni}, \mathrm{Pb}, \mathrm{Si}, \mathrm{Sr}, \mathrm{Ti}$ and Vin 42 cosmetic samples, including 21 artificial cosmetics, 21 traditional and natural cosmetics using ICP-OES technique. 


\section{Experimental work}

\section{Sample collection}

Forty two samples including one part of twenty one artificial cosmetics of several brands and prices were purchased from markets in Libya and Egypt as shown in tables 2 and 4.

\section{Sample preparation}

Samples digestion: $0.15 \mathrm{~g}$ of sample, $7 \mathrm{ml}$ high purity Nitric Acid and 2 $\mathrm{ml}$ high purity hydrofluoric acid are added to a microwave vessel and the samples are heated over 15 minutes to $130^{\circ} \mathrm{C}$. Then,samples are held at $130^{\circ} \mathrm{C}$ for three minutes before the temperature is ramped to $200^{\circ} \mathrm{C}$ over 15 minutes and held at $200^{\circ} \mathrm{C}$ for 30 minutes. After that, $30 \mathrm{~mL}$ of $4 \%$ high purity Boric Acid solution is added to the vessels (A 4\% Boric Acid solution has been added after digesting to neutralize the Hydrofluoric acid) then, the samples are heated again in the microwave to $170^{\circ} \mathrm{C}$ over 15 minutes and held for 10 minutes at $170^{\circ} \mathrm{C}$. The samples are then diluted to $50 \mathrm{ml}$ usingdistilled $\mathrm{H}_{2} \mathrm{O}$.

The trace element analysis is performed using Thermo scientific iCap 7000 series ICP-OES spectrometerin Laboratories Compound of Desert Research Center of Egyptian Ministry of Agriculture and Land Reclamation.

\section{Results}

The results ofthe present work are illustrated in tables (2) and (5); from these tablesSr, $\mathrm{V}$ and Mohavelow concentrations and do not have negative effects in most samples. While the concentrationsof Siarehigh in all samples. It is non-toxic and it is inert material.

According to table (2) which lists the sample's name, codes, origin country, color and heavy elements concentrations, the concentrations of $\mathrm{Cd}$ and $\mathrm{Hg}$ in all samples are less than the allowable levels [1] [2]. Also, the concentrations of $\mathrm{Ti}$ are higher than the allowable level in some samples, but stable Tiis not a poison metal except for some effects on thelungs. If inhaled at high rates, it will not remain inside the body and the body can overcome it easily. 
Regarding to table (2), the concentrations of all elements are in acceptable levels [1][2] in foundation creams and compact powder samples with the exception of As in SFL34 which are (15.95 ppm), and foundation cream is applied on the face and can uptake through the mouth. In lipsticks and lip-glosses, the heavy elements concentrations in Italian made brands having expensive prices are lower than those in Chinese and samples of unknown sources

In eye cosmetics, the concentrations of $\mathrm{Pb}$ and $\mathrm{Cr}$ are high in alleye shadow samples and Co is high in rose and blue samples. It is known that the eyelid skin is very thin and the applying of such contaminated eye shadows can cause irritation, concerning samples of mascara and eyeliner, most of theelements concentrations are at acceptable levels. Althoughthe last one is from unknown source and inexpensive, it has low concentration of $\mathrm{Pb}$. In body powder sample, the concentration of $\mathrm{Cr}$ is $11.78 \mathrm{ppm}$ and $28.71 \mathrm{ppm}$ of $\mathrm{Pb}$. These relatively high concentrations can cause several health effects with daily use especially for childrendue to the higher probabilityabsorbing through the mouth. While in the German hair dye sample all the elements were below allowable levels. In Israeli hand cream samples, arsenicis recordedhigherconcentrations than all other ones (43.37 and $52.71 \mathrm{ppm})$. Oral contamination can occur from hand-to-mouth contact after using contaminated hand creams and also these high concentrations may be absorbed through the skin.

The results of this work show high rates of heavy elements contamination in some samples compared to other results as shown in Table (3). 


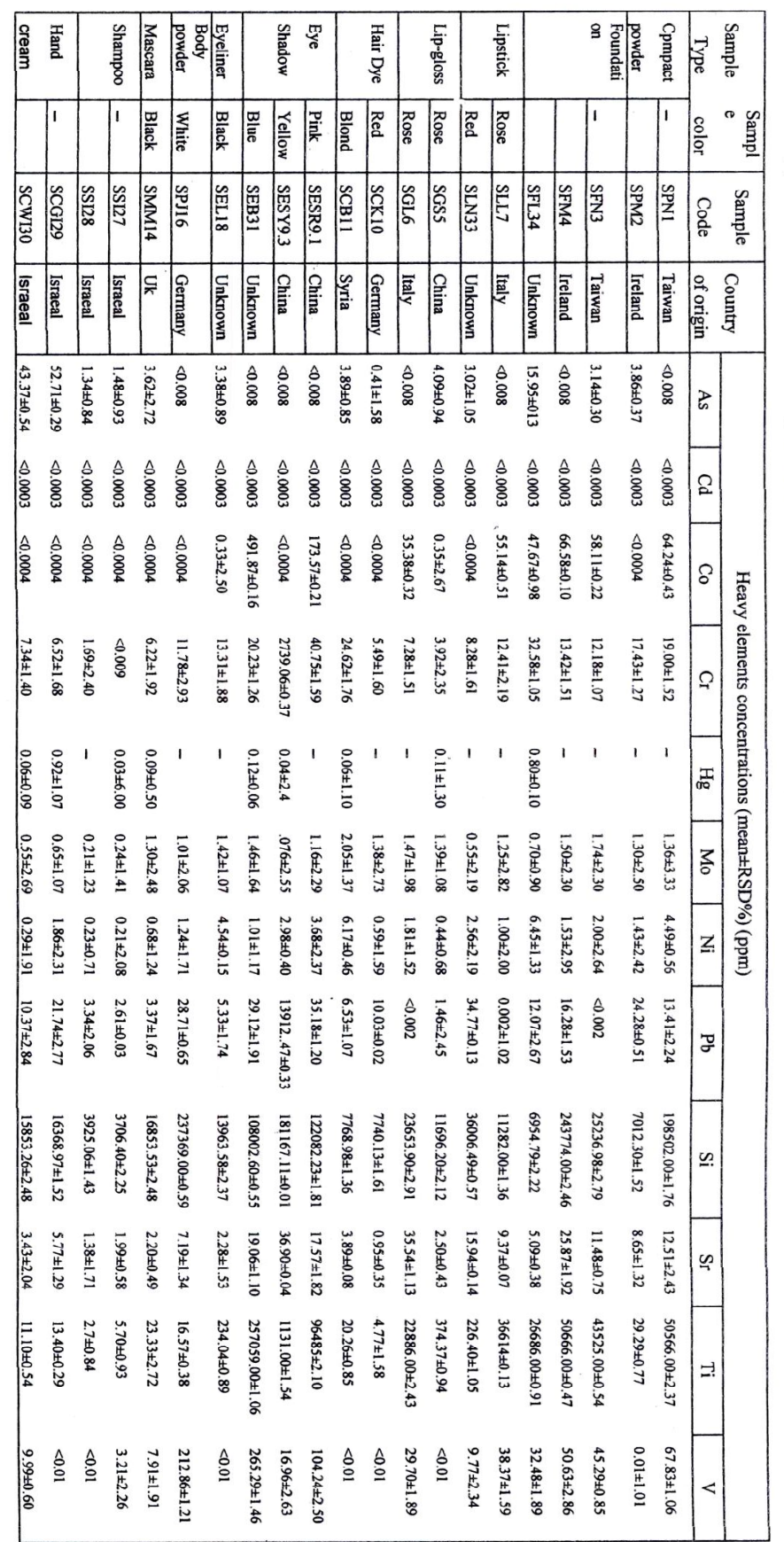


Table (3) comparison between our results and other studies' results

\begin{tabular}{|c|c|c|c|c|c|}
\hline \multirow[t]{4}{*}{ Cosmetic type } & \multirow[t]{4}{*}{ Study Information } & \multicolumn{4}{|c|}{ Results $\quad(\mathrm{ppm})$} \\
\hline & & & Concern & & Not \\
\hline & & $(<\mathrm{CL}=$ & Level & $\mathrm{Nm}$ & Measured) \\
\hline & & $\mathrm{Pb}$ & As & Co & $\mathrm{Cr}$ \\
\hline \multirow[t]{2}{*}{ Eye shadow } & This work & 35.18 & $<\mathrm{CL}$ & 491.87 & 2739.06 \\
\hline & M.G. Volpe et al.'s (2012) [8] & 81.58 & NM & $<\mathrm{CL}$ & $<\mathrm{CL}$ \\
\hline \multirow{4}{*}{$\begin{array}{l}\text { Lipsticks } \\
\text { and } \\
\text { lipglosses }\end{array}$} & This work & 34.77 & 4.09 & 55.14 & 12.41 \\
\hline & Paola Piccinini et al.'s (2013), [9] & 3.75 & NM & NM & NM \\
\hline & $\begin{array}{c}\text { Canadian environmental } \\
\text { defence (2011), [10] }\end{array}$ & 110 & 70 & NM & NM \\
\hline & Iman Al-Saleh et al.'s (2009), [3] & 3760 & NM & NM & NM \\
\hline
\end{tabular}

Regarding health riskassessment,Loretz et al.'s (2005) [11] calculated the daily usage of lipsticks by 360 women aged(18-65) over two weeks.The outcome of this study in average is 2.35usesof lipstickper day. The mean quantity of lipstick used per day was $(0.024 \mathrm{~g})$. Also, we have done a rough estimationof 20 females in the vicinity of family and work on the number of times of their daily usage of lipsticks. The results were higherthanLoretz's results because the hot weather in Arabic regions makes women applying makeup more than one time a day. Therefore, we calculate the weekly absorption rate of heavy elements as Loretz's results on the base that lipstick is fully ingested(this is very possible, especially while eating).According to table (4) the weekly rate of heavy metals from cosmetics is not high (some micro grams a week). However, there is a weekly absorption from other sources: dust inhalation, water, food ingestion and contact with toys making these weekly rates more effective due to the influence of heavy metals(accumulative).

Table (4) The amounts of heavy elements weekly absorbed into the bodyas a result of using lipsticks

\begin{tabular}{|l|l|cccc|}
\hline \multirow{2}{*}{$\begin{array}{l}\text { Sample } \\
\text { Type }\end{array}$} & \multirow{2}{*}{$\begin{array}{l}\text { Sample } \\
\text { Code }\end{array}$} & \multicolumn{4}{|l|}{$\begin{array}{l}\text { Weekly exposure of some heavy } \\
\text { elements from lipsticks (in } \mu \mathrm{g})\end{array}$} \\
\cline { 6 - 6 } & & As & Co & Cr & Pb \\
\hline \multirow{2}{*}{ Lipstick } & SLL7 & - & 9.26 & 2.08 & - \\
& SLN33 & 0.51 & - & 1.39 & 5.84 \\
\cline { 2 - 2 } Lip-gloss & SGS5 & 0.69 & 0.06 & 0.65 & 0.25 \\
\cline { 2 - 2 } & SGL6 & - & 5.94 & 1.22 & - \\
\hline
\end{tabular}

The results of heavy elements concentrations in traditional cosmetics are registered in table (4). It is clear that Yemeni henna sample has the mostacceptable concentrations of heavy elements comparing with other 
henna samples.Concerning hair dyeing,the German dye sample in Table (2) has heavy elements concentrations lower than those in all henna samples.

According to talc stone which is a row material used to make body powders, the concentrations of $\mathrm{Pb}$ and $\mathrm{Hg}$ are so high [2475.81 and 22.93 ppm, respectively] comparing with allowable levels [1] [2] and also comparing with those in body powder sample in Table (5).

Nevertheless, kohl as a traditional eyeliner in Arabic regions, the results show that the concentrations of $\mathrm{As}, \mathrm{Cd}, \mathrm{Cr}$ and $\mathrm{Pb}$ are higher than the allowable levels. But $\mathrm{Hg}$ has high concentrations only in 3 samples (see table 4). The concentration of Pbin powderedkohl sample imported from India is $2771 \mathrm{ppm}$ which is so high, but it is relatively low to kohl-stone samples (748344.54 ppm 74\%) .The concentrations of $\mathrm{Cd}$ which have low values in all other samples are ranged between[8.00 - $39.87 \mathrm{ppm}]$ in kohlstone samples.A study in KSA (Kingdom of Saudi Arabia) [12] has shown the lead concentrations in imported samples available in KSA ranged between 0.004 to $53 \%(40$ to $530000 \mathrm{ppm})$.Also ,these results illustrates reduction of hemoglobin and increase of lead blood level for individuals using kohl comparing with those who have never used kohl.Another study indicatedto a high level of lead in cataract lenses in comparison with clear lenses [13].

Historically, kohl is an Arabic name, while 'stibium', known as 'Athmad' or 'Al-ithm1 d,' was Latinized as 'athimodium,' 'atimodium,' 'atimonium,' 'antimonium.' Similarly, the name surma is derived from the word for antimony .Several prescriptions given in Eastern pharmacop-oeias include antimony, zinc and lead. Antimony first appeared in a chemical literature of the renaissance period, and BasiliusValentinus (1565- 1624) wrote a monograph on it in 1604. Actually, antimony, in the form of its sulphide (stibnite, Sb2S3), has been known in Eastern countries at very early times .A reference was made to antimony in the Old Testament. It was used for making cosmetics such as rouge and black paint for eyebrows, and was confused with lead. This information provides considerable evidence to support the suggestion that earlier types of kohl mainly contained antimony sulphide. As antimony sulphide became scarce, it was replaced by lead sulphide and lead oxide [12].

Most Arabic women applied kohl at a rate of one to two times daily. We have approximately found the amount $(0.08 \mathrm{~g})$ of kohl could the user 
applied per time for all samples given in table (4). Since we cannot estimate the exact amount absorbed into the body from the used weight, kohl can be ingested or entered through the tear duct. However, we can roughly assume that about $50 \%$ of applying kohl is absorbed into the body and then calculate the amount of four most toxic metals absorbed per year by using kohl one time a day. The results are shown in table (5).

Table (5)The amounts of heavy elements absorbed per year into the body as a result of using kohl

\begin{tabular}{|c|c|c|c|c|}
\hline \multirow{2}{*}{$\begin{array}{l}\text { Sample } \\
\text { Code }\end{array}$} & \multicolumn{4}{|c|}{$\begin{array}{l}\text { The amount of heavy elements absorbed annually } \\
(\mathrm{mg})\end{array}$} \\
\hline & As & $\mathrm{Cd}$ & $\mathrm{Pb}$ & $\mathrm{Hg}$ \\
\hline SEL18 & 1.23 & Nil & 1.95 & Nil \\
\hline SKA17 & Nil & Nil & 1011.55 & 0.03 \\
\hline SKK20 & 2.27 & 2.92 & 18493.33 & Nil \\
\hline SKP22 & 4.95 & 14.55 & 199982.20 & 0.01 \\
\hline SKI23 & 1.66 & 7.03 & 205994.80 & Nil \\
\hline SKK24 & 4.10 & 2.76 & 192561.55 & 0.02 \\
\hline SKA1 & 2.59 & 2.87 & 258067.35 & 25.13 \\
\hline SKR2 & 38.73 & 2.33 & 244547.57 & 24.78 \\
\hline SKL3 & 1.64 & 5.69 & 273145.76 & 55.68 \\
\hline
\end{tabular}

The US FDA warned not to use the present Kohl as color additive in any of the products and barred entry to the United States based on kohl contaminated of lead. Kohl is a color additive as that term is defined in the Federal Food, Drug and Cosmetic Act (FD\&C Act).There is no regulation permitting its use in a cosmetic or in any other FDA-regulated product [14].

\section{Conclusion:}

In this study, we determine high concentrations of $\mathrm{As}, \mathrm{Cr}, \mathrm{Co}, \mathrm{Ni}$ and $\mathrm{Pb}$ in the various samples, particularly those cheap ones in natural materials especially in samples of kohl stones.

Women are advised not to use cosmetic products frequently and to choose the surest brands leaving the cheap products, especially in lipsticks and eye cosmetics. Using kohl, based on this study and other studies, women should be notified that current widespread of Kohl on the markets is not genuine and unhealthy. On the contrary, highly toxic of lead, other heavy metals and the need to stop using it completely for them and for their children. We recommend that necessary make Agency to protect consumer from contaminated material 


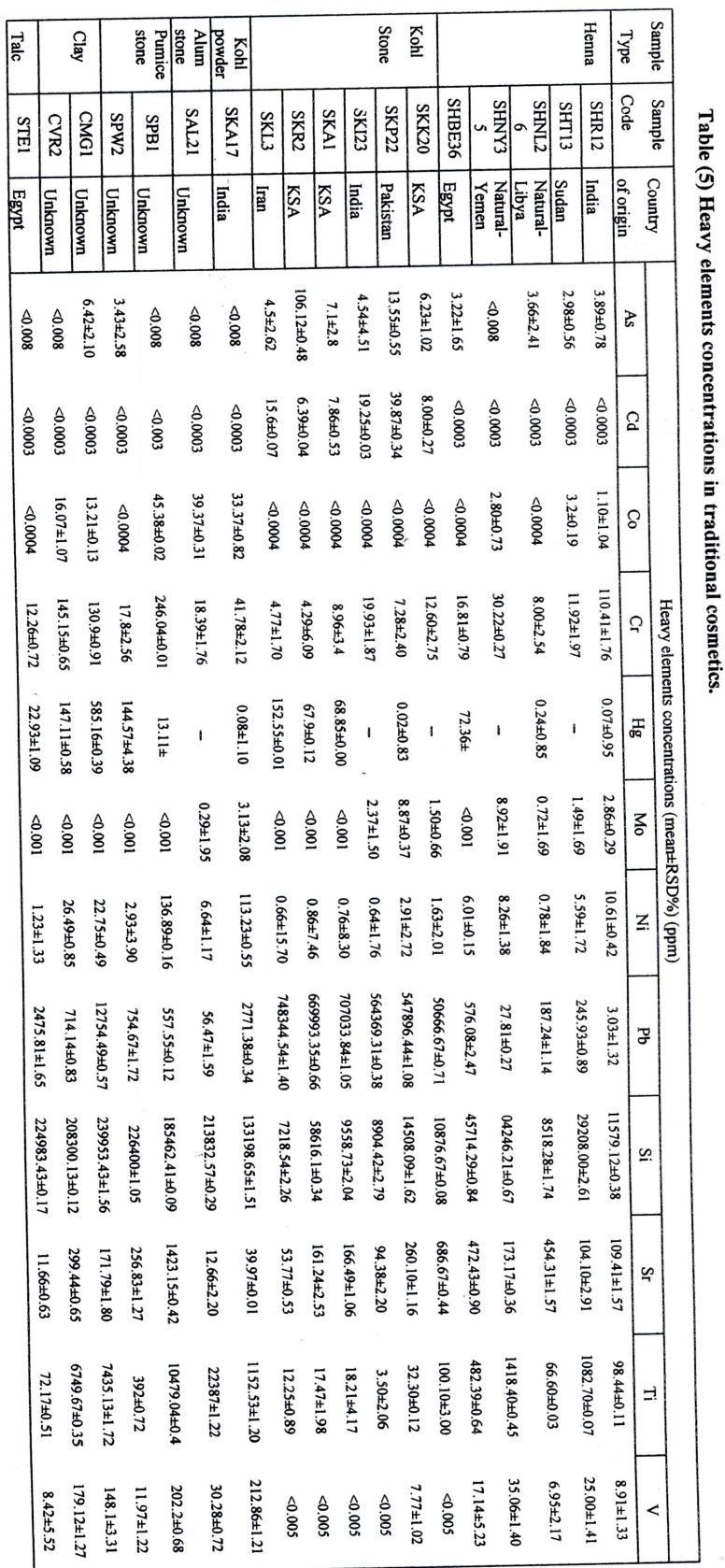




\section{Acknowledgment}

As authors of this research, we acknowledge our debt to all researchers working in the High Energy Physics Laboratory at Cairo University . Furthermore, we are extremely grateful to Prof. Nagdya M. Ibrahiem (professor in Egyptian atomic Agency) who provides this work with her great deal of experience and valuable knowledge.

\section{References}

1. Health Canada, consumer product safety, Guidance on Heavy Metal Impurities in Cosmetics. http://www.hc-sc.gc.ca

2. U.S. Food and Drug Administration, Color Additives Approved for Use in Cosmetics http://www.fda.gov/ForIndustry/ColorAdditives/ColorAdditiveInventories/ucm115641.ht m\#table $3 \mathrm{~A}$

3. Iman Al-Saleh, Sami Al-Enazi, Neptune Shinwari, 2009 . Assessment of lead in cosmetic products. vol54, Pp105-113, Regulatory Toxicology and Pharmacology.

4. R.W. Gorter, M. Butorac, E.P. Cobian, 2005. Cutaneous resorption of lead after external use of lead-containing ointments in volunteers with healthy skin (Am. J. Ther. 12, 17-21)

5. Environment Canada \& Health Canada, 1993. Priority Substances List Assessment Report: Arsenic and its Compounds. Retrieved November 5, 2010 http://www.hc-sc.gc.ca/ewh-semt/pubs/contaminants/psl1-1sp1/arsenic_comp/indexeng.php

6. Agency of Toxic Substances and Disease Registry, 2008. Toxicological Profile for Cadmium. Retrieved November 5, 2010 (http://www.atsdr.cdc.gov/toxprofiles/tp.asp?id=48\&tid=15)

7. Lauwerys, R. R., Bernard, A. M., Roels, H. A., \&Buchet, J. P, 1994. Cadmium: exposure markers as predictors of nephrotoxic effects. vol 40 (7 Part 2), Pp 1391-1394, Clinical Chemistry.

8. M.G. Volpe, M. Nazzaro, R. Coppola, F. Rapuano, R.P, 2012. Aquino. Determination and assessments of selected heavy metals in eye shadow cosmetics from China, Italy, and USA. vol101, Pp 65-69, Microchemical Journal.

9. Paola Piccinini, MałgorzataPiecha, Salvador Fortaner Torrent, 2013. European survey on the content of lead in lip productsvol 76, Pp 225-233, Journal of Pharmaceutical and Biomedical Analysis.

10. Canadian environmental defence, May 2011 . The Health Risks of Hidden Heavy Metals in Face Makeup.

11. Loretz, LJ; Api, AM; Barraj, LM; Burdick, J; Dressler, WE; Gettings, SD; Han Hsu, H; Pan, YHL; Re, TA; Renskers, KJ; Rothenstein, A; Scrafford, CG; Sewall, C, 2005. Exposure data for cosmetic products: Lipstick, body lotion, and face cream. vol $43 \mathrm{Pp}$ 279-291, Food and Chemical Toxicology.

12. R.M. Al-Ashban, M. Aslam, A.H. Shah, 2004. Kohl (surma): a toxic traditional eye cosmetic study in Saudi Arabia. vol118,Pp 292-298, Public Health.

13. Nandita Shukla, J.K. Moitra, R.C. Trivedi, 1996. Determination of lead, zinc, potassium, calcium, copper and sodium in human cataract lenses. vol 181, Pp 161-165, The Science of the Total Environment.

14. U.S. Food and Drug Administration, Cosmetics, Kohl, Kajal, Al-Kahal, or Surma: By Any Name, a Source of Lead Poisoning http://www.fda.gov/Cosmetics/ProductandIngredientSafety/ProductInformation/ucm1372 50.htm 
